\title{
Recent Advances in Anammox Bioreactors for Industrial Wastewater Reuse
}

\section{Mostafa MG*}

Institute of Environmental Science, University of Rajshahi, Bangladesh

Water is an essential commodity for all human activities including drinking, agricultural and industrial purposes. In fact, total global water use increases at almost three times faster than the population growth rate [1]. Industrialization has further aggravated the water scarcity problems. Untreated industrial effluents produce huge pollution and create great difficulties in managing nitrate emissions to water bodies. Wastewater treatment needs greater emphasis due to the trends in rapid industrial and urban development. Currently there is an increase in the awareness of the impact of untreated industrial effluents contamination on rivers and lakes, wastewater treatment is now receiving greater attention from the government regulatory bodies and environmental concerns organization. Wastewater reuse is essential for the sustainability of water uses in various purposes.

Anammox is a new and emerging technology which reflects greater concern for the environment. It is an almost completely unexplored part of the biological nitrogen cycle [2] and this process opens a new era for wastewater treatment. Anaerobic Ammonium Oxidation is abbreviated as Anammox, the bacterial process was identified in 1999, and Anammox is also the trademarked name for an ammonium removal technology [3]. The biological process usually takes place in many natural environments and the discovery of anammox process was a great achievement for wastewater reclamation and reuse.

Mulder et al. [4] discovered anammox process about 15 years ago where dinitrogen gas was produced from directly combining ammonium and nitrite. Nitrite and nitrate are subsequently reduced to nitrogen gas by denitrifying bacteria under anoxic conditions. Anammox process is considered to have high potentials for high Nitrogen Removal Rate (NRR) from wastewaters containing low C/N ratio or high ammonium concentration, such as landfill leacheate and sludge digester liquor [5]. The autotrophic process has promise in being part of improving the sustainability of wastewater treatment in that it reduces the need for carbon addition, oxygen consumption and the emission of nitrous oxide during oxidation of ammonia [6]. In practical terms, these virtues have interested the wastewater treatment industry because they translate to lower energy consumption, lower sludge production and environmental friendly gas generation. It offers several advantages over the well established industrial equivalent, nitrification-denitrification, including higher nitrogen removal rate, lower operational cost and less space requirement. Anammox also has great potential in reducing $\mathrm{CO}_{2}$ emissions by up to $90 \%$ and considered to be a 'green' process and considering the need to reduce our emissions. As an emerging water treatment process, several studies have been conducted on various ammonium-rich wastewaters. In one example, anaerobic digestion of livestock manure effluent is practiced due to several advantages such as no oxygen requirement, low sludge production and generation of methane gas for energy recovery $[7,8]$.

However, much like any microbial process, anammox reactors need specific conditions to create the environment needed for the bacterial growth and its activities during the operation period. The difficulty in retaining slow-growth anaerobic microorganisms, Longer Hydraulic Retention Time (HRT), and controlling biological activities inside the reactor are the main concerns for its industrial applications. Thus, the researchers are targeting rapid anammox culture and enrichment process and as well as high performance nitrogen removal at a shorter HRT to sustainable industrial application. The anammox growth depends on sludge characteristic, anammox species, feeding media, temperature, $\mathrm{pH}$ and other physico-chemical environments.

A Membrane Bioreactor (MBR) could be useful in addressing the issues preventing wider industrial uptake of anammox, as the membranes are highly effective at retaining biomass, particularly since they don't require the solids to possess the settling property as would be needed for gravity based separators (e.g. clarifiers). An MBR configuration for culturing anammox bacteria revealed that a Solids Retention Time (SRT) as low as 12 days can be achieved (i.e. doubling times were less than 10 days, compared to up to 30 days for conventional anammox reactors) [9]. Another issue is the difficulty in sourcing locally adapted anammox biomass to initiate pilot trials. Membrane fouling is a major operational issue for a SAnMBR. Several strategies have been used to minimize membrane fouling, including interval operation, sub-critical flux operation, periodic physical or chemical cleaning, etc. Researchers are working on membranes coupled with Anammox bioreactor and their associated process as a means to manage fouling and conveniently grow anammox cultures from naturally occurring sources. Although, Anammox process has revealed a lot of interesting facts, but still it is in a very beginning state. There are a lot of exiting aspects of anammox process to be focus in further research.

\section{References}

1. Biswas AK (1997) Water Resources: Environmetal Planning, management, and Development. Tata McGraw-Hill Publishing Company Ltd., New Delhi.

2. Arrigo RK (2004) Marine Microorganisms and global nutrient cycles. Nature 437: $349-355$

3. Jetten Michael Silvester Maria, Van Loosdrecht Marinus Corneli; Technische Universiteit Delft, patent WO9807664.

*Corresponding author: Mostafa MG, Institute of Environmental Science, 4th Science building, University of Rajshahi, Rajshahi 6205, Bangladesh, E-mail: mostafa_ies@yahoo.com

Received August 05, 2012; Accepted August 06, 2012; Published August 10 , 2012

Citation: Mostafa MG (2012) Recent Advances in Anammox Bioreactors for Industrial Wastewater Reuse. J Pet Environ Biotechnol 3:e108. doi:10.4172/2157$7463.1000 \mathrm{e} 108$

Copyright: (c) 2012 Mostafa MG. This is an open-access article distributed under the terms of the Creative Commons Attribution License, which permits unrestricted use, distribution, and reproduction in any medium, provided the original author and source are credited. 
Citation: Mostafa MG (2012) Recent Advances in Anammox Bioreactors for Industrial Wastewater Reuse. J Pet Environ Biotechnol 3:e108. doi:10.4172/2157-7463.1000e108

Page 2 of 2

4. Mulder A, van de Graaf AA, Robertson LA, Kuenen JG (1995) Anaerobic ammonium oxidation discovered in a denitrifying fluidized bed reactor. FEMS Microbiol Ecol 16: 177-184

5. Strous M, Heijnen JJ, Kuenen JG, Jetten MSM (1998) The sequencing batch reactor as a powerful tool for the study of slowly growing anaerobic ammoniumoxidizing microorganisms. Appl Microbiol Biotechnol 50: 589-596.

6. Jetten MSM, Horn SJ, van Loosdrecht MCM (1997) Towards a more sustainable wastewater treatment system. Water Science and Technology 35: 171-180.

7. Baykov B, Stoyanov M, Gugova M (1995) Methane fermentation of dung from litter-free reared domestic animals-an optimization study. Resour Conserv Recycl 13: 251-256.

8. Hill DT, Bolte JP (2000) Methane production from low solid concentration liquid swine waste using conventional anaerobic fermentation. Bioresour Technol 74 241-247.

9. van der Star WRL, Miclea Al, van Dongen UGJM, Muyzer G, Picioreanu C, et al. (2008) The Membrane Bioreactor: A Novel Tool to Grow Anammox Bacteria as Free Cells. Biotechnology and Bioengineering 101: 286-294. 